MedieKultur | Journal of media and communication research | ISSN 1901-9726

\title{
The mediatization of journalism
}

\section{Aske Kammer}

MedieKultur 2013, 54, 141-158

Published by SMID | Society of Media researchers In Denmark | www.smid.dk The online version of this text can be found open access at www.mediekultur.dk

Proposing an explanation of current macro-sociological changes and institutional transformations in journalism, this article argues that journalism is currently undergoing a process of mediatization. Drawing upon the international research literature as well as statements from interviews with news workers working on Danish news websites, the article examines four current trends in journalism that are closely connected to the rise of news on the web, namely the use of the affordances of news websites, radical commercialization, increased audience participation in news production, and the increased multi-skilling and simultaneous de-skilling of journalists. Taken together, these trends reflect a process through which journalism increasingly subsumes itself to the logic of the media, suggesting mediatization as an adequate explanatory framework. One implication of such a process is that journalism seems to be transforming from an occupational profession into an organizational one.

\section{Introduction}

Reviewing some of the most prominent trends in contemporary journalism and news on the web, this article argues that the developments currently taking place within journalism can beneficially be understood as a process of mediatization. That is, journalism is increasingly subordinating itself to the imperatives of the media institution and the media logic it 
sustains, thereby changing the institution's very professionalism. The article focuses on the branches of journalism that have to do with making news for digital media in general and on the web in particular. News production for the web obviously constitutes just a subset of contemporary journalism, but because it is a subset that condenses larger trends within journalism and can simultaneously be expected to become even more important in the years ahead, it allows us to draw more general conclusions about the current condition of journalism. It can be a case with which to make broader inferences concerning journalism.

According to Örnebring (2009), the very professionalism of journalism is undergoing a transformation as greater attention is being granted to organizational demands, and among both practitioners and scholars, there is general agreement that journalism is currently affected by significant change. This is a claim that constitutes an undercurrent through most contemporary journalism research, regardless of whether it focuses on journalistic production practices (see Anderson, 2013; Boczkowski, 2004; Deuze, 2007, 2008, 2011; Hartley, 2011), channels of distribution (Bødker, forthcoming/2013; Newman, 2011; Wallberg, 2012), convergence within and across different media organizations (Erdal, 2008; Krumsvik, 2009), journalists' relationships with audiences (Domingo, 2008; Hermida \& Thurman, 2008; Singer et al., 2011; Steensen, 2011), content (Ilebekk, 2000; Steensen, 2010; Thurman \& Walters, 2013; van der Wurff \& Lauf, 2005), business models (Barland, 2012; Bruno \& Nielsen, 2012; Grueskin, Seave, \& Graves, 2011; Nielsen, 2012), or any other particular subfield. The majority of the academic literature on digital news and journalism, most of which takes the form of focused empirical analyses, is characterized by scant attention being paid to overarching explanatory models for coming to terms with the processes at work over recent years for journalism as an institution, for how journalism is changing on an institutional level.

This article proposes mediatization as a theoretical framework with which to understand these macro-level developments and structural changes within journalism. One prominent approach to mediatization is that it is a theoretical perspective that provides a framework for understanding and analyzing the institutional changes that result from the media constituting an institution in its own right (Hjarvard, 2004, 2008a, 2008c; Schrott, 2009). Applying this approach to journalism, however, builds upon two underlying assumptions: first, that journalism is an institution and second, that this institution is not the same as the media institution even though the two are closely related and partially overlap.

The media institution, on the one hand, is a diverse and complex constellation of different types of media with various formats, presentational characteristics, audience perceptions, and processes of production and consumption (Hjarvard, 2008a, 2008c). Because of this, the media institution appears somewhat diffuse as it does not consist of stable social patterns of rules and resource as institutional theory stipulates (see, e.g., Giddens, 1984, 1986). The institution of journalism, on the other hand, relates strictly to certain rules and resources (see below) and concerns the production and public dissemination of new knowledge concerning current events. The line between these two institutions (to the degree that one can talk about the media institution) is, however, a fine one and is often blurred. One 
reason for this blurring is that, historically, journalism has developed within the context of the media and has, as such, been shaped and influenced from the start by the media's principles of operation. As long as news has been carried by media technologies, the people producing the content (be they professionals or amateurs) have had to tailor what they made to fit the setting that the medium represented. Furthermore, the logic of the media, to which other institutions accommodate when they become mediatized (see below), is actually first and foremost the formats of journalism. For example, when researchers discuss the mediatization of politics (Mazzoleni \& Schulz, 1999; Strömbäck \& Esser, 2009), it often relates to how political actors adjust their behavior and the presentation of their messages in order to accommodate the news values and formats of journalism.

Furthermore, the approach applied here presupposes an institutional perspective on journalism. Such a position is proposed, for instance, by Cook (2005), who draws upon a social science framework presented by Huntington and Dominguez (1975) in which institutions have three distinct characteristics. First, they comprise a shared set of social patterns, norms, and understandings of adequate behavior. Within journalism, these kinds of social patterns exist in institutionalized practices such as the shared recognition of newsworthiness, common acknowledgement of valuable beats, an understanding of the news media as the fourth estate of society, etc. Second, institutions extend over time and space. Here, Cook is in line with Giddens, who defines institutions as the "practices which have the greatest time-space extension" (1984, p. 17). However, as the conclusion of this research article also illustrates, extension across time and space does not imply that institutions cannot develop or change although it is clear that, despite historical developments, the basic constituents of journalism remain relatively stable. Third, institutions preside over social domains. Just as, for example, the political institution attends to the distribution of values in society (Easton, 1971), journalism manages the production and public circulation of new and contextualized knowledge on current affairs.

There are thus grounds for regarding journalism as an institution even though competing perspectives on journalism do, of course, exist. A particularly prominent perspective is that of journalism as a culture (Russell, 2011; Zelizer, 2005), which regards it as "a complex web of meanings, rituals, conventions and symbol systems" (Zelizer, 2005, p. 198). From this perspective, journalism is primarily a belief system and a set of work practices in accordance with which members of the profession behave. In a related conceptualization, Deuze (2005) emphasizes the ideological aspects of journalism. But both the cultural and the ideological perspectives on journalism seem to cover only parts of what journalism is. While both undeniably constitute valid and valuable contributions to the understanding of the work journalists do, they nevertheless fall short of encompassing journalism in its entirety since they neglect journalism's societal commission with their emphasis on the concrete practices and beliefs. But as Eide underscores, "the self-perception of the profession is tied to its having a democratic key role to play" (Eide, 2011, p. 11, my translation), and this political and societal dimension of journalism is found primarily in the institutional perspective. 


\section{Empirical basis}

Empirically, the argument put forth in this article rests first and foremost upon the existing scholarly literature on news on the web. However, I use statements from semi-structured lifeworld interviews (Kvale, 1997) with news workers to illustrate points from the literature. These interviews were conducted as part of an inquiry into journalistic transformations (Kammer, 2013). A total of 13 news workers from Danish and American news websites were interviewed from June 2011 to April 2012. The interviews focused on news workers' considerations on and perceptions of working with news websites and the professional transformations connected with such work. The interviewees were selected in order to obtain variety in terms of editorial categories in the newsroom and seniority (ranging from technical staff to editors-in-chief and from news workers with only a couple of years' experience to one who was very close to retirement) as well as in terms of the kinds of news websites at which they work (ranging from The New York Times to the hyper-local Kjerteminde Avis, which covers a municipality with a population of approximately 23,500).

\section{Mediatization theory}

As mediatization is still a relatively new contribution to the vocabulary of media and communication research, its exact meaning remains contested (Lundby, 2009a). A particularly prominent perspective, however, is that of mediatization theory as an institutional (or macro-sociological) theory. From this point of view, advocated by Hjarvard $(2004,2005$, 2008a, 2008b, 2008c, 2009, 2010, 2012a, 2013; Hjarvard \& Finnemann, 2009) in particular and also by Schrott (2009), mediatization is a geographically and historically contingent process that accelerated in the second half of the 20th century in highly industrialized societies in which the media began developing into a social institution in its own right. While the media formerly operated in the service of other institutions (for instance, as conveyors of messages from the political or religious institutions), they now primarily serve themselves. As the media have gained institutional autonomy and have simultaneously come to play a central role in a modern society in which media presence is crucial for social actors, other institutions of society have begun accommodating the logic of the media. By doing so, they become mediatized: "The core of mediatization consists in the mechanism of the institutionalization of media logic in other societal subsystems" (Schrott, 2009, p. 42).

As a foundation for this summation, Hjarvard defines mediatization basically as "the process whereby society to an increasing degree is submitted to, or becomes dependent on, the media and their logic" (Hjarvard, 2008c, p. 113). Here, Hjarvard only refers explicitly to 'society' as that which is being mediatized, but it is clear from his additional writing on mediatization (e.g. Hjarvard, 2008a, 2012a, 2013) that 'society' also encompasses its various institutions and the activities within them. As mediatization thus applies to different institutions or spheres of society and has different impacts, Hjarvard (2004) introduces a distinction between weak and strong mediatization. By strong mediatization, he refers to 
processes by which activities that were previously not dependent on media assume mediated form; weak mediatization, on the contrary, relates to processes by which activities are merely increasingly influenced by media logic.

One particularly vocal critic of the theory of mediatization is Couldry (2008), who takes exception to two points in the theoretical framework despite later embracing parts of it (see Couldry, 2012). To begin with, he critiques the framing of mediatization as a linearly progressing historical development "from 'pre-media' (before the intervention of specific media) to 'mediatized'" (Couldry, 2008, p. 375), arguing that such a linear perspective cannot capture the plurality of dynamics that are at play in the changes in and transformations of different social institutions. More central in Couldry's critique are his reservations concerning mediatization theory's underlying assumption of a media logic. Media logic, which both Hjarvard (2008a, 2008c) and Schrott (2009) explicitly reference as a conceptual cornerstone of mediatization theory, was introduced by Altheide and Snow (1979) to describe how media work and which forms and formats they indirectly privilege and sustain.

The critique from Couldry - which has also been voiced by, for example, Lundby (2009b) - addresses the notion that one such media logic should exist. Encircling the concept, Hjarvard specifies that by 'media logic', he understands "the institutional, technological and expressive characteristics of media" (Hjarvard, 2008c, p. 126), but Couldry objects that the various media are not necessarily characterized by the same things; on the contrary, there will often be fundamental differences between the institutional, technological, and expressive (i.e. aesthetic or rhetorical) modes of operation of different media. The logics that guide the workings of a Hollywood movie are quite different from those guiding newspapers. Different logics are at work with different media, and Couldry considers mediatization theory reductionist because it cannot conceive of the heterogeneous developments and transformations.

However, the necessity that follows from this position of differentiating media logic already seems to be inscribed in Hjarvard's conceptualization of mediatization theory as he accentuates how the concrete instances of mediatization must always be subject to empirical analysis (Hjarvard, 2004). Such analyses must also include an exposition of the specific mediagenic context in question. As such, Couldry and others are correct when they dispute the idea of one media logic as a structuring force relative to the institutions of society. But within mediatization theory, media logic might above all be a heuristic device that should be subject to empirical analysis and contextualization when applied in a concrete research situation.

Being an institutional theory, mediatization theory occupies itself primarily with developments and changes on a macro level while processes on a mezzo and micro level are rarely the subject of mediatization research (Petersen, 2012). Attention to social and cultural change often results in a focus on structural questions, and the relationship between macro processes of mediatization and micro processes of social behavior remains a blind spot for most mediatization research. This tendency echoes the central questions of sociol- 
ogy, namely determining the relationship between structure and agency and identifying the role that individual human actors play in structural change. Schrott (2009), however, addresses this blind spot and asks how social structures and situations on the macro level translate into individual behavior on a micro level as well as how this behavior in turn influences what happens at the macro level.

According to Schrott, mediatization processes occur in the mutually dependent interplay between social situations and individual behavior. To begin with, social situations and structures are affected by the media's status as independent institutions. For this reason, the media and their logic have to be taken into consideration by human actors who must respond to the social situations in which they find themselves in the course of their everyday activities. These considerations naturally influence the individuals' behavior, which will according to Schrott's inspiration from rational choice sociology - be in the form of a rational adjustment to the demands and formats of the media. The adjusted behavior will, then, have consequences for the social situations, which take the media into account and accommodate to their logic. At this point, the situation (or structure or institution, if you will) is increasingly mediatized because it has accommodated to the media logic. Mediatization is thus constituted in the mutually influencing and moulding relationship between institutions and the actors that reproduce, maintain, and develop them through their agency. Although Schrott does not mention it, this perspective on the mediatization processes obviously echoes Giddens' theory of structuration (Giddens, 1984), which similarly emphasizes the mutually moulding interplay between social situations and individuals' behavior.

The question, then, is how this theoretical framework relates to current developments within journalism.

\section{Four trends in contemporary journalism}

In this section, I will address four prominent trends in contemporary journalism as expressed through news on the web. The four trends, which I will go through one by one, are: 1) the use of the affordances of news websites, 2) radical commercialization, 3) increased audience participation in news production, and 4) the increased multi-skilling and simultaneous de-skilling of journalists. Precisely these four trends are chosen because they represent the most striking examples of how journalism, exemplified by news production for the web, is developing. It is the claim of this article that, taken together, these trends indicate that a mediatization process is taking place within the institution of journalism.

\section{1) The use of the affordances of news websites}

The first trend is the use of the affordances of news websites. News websites differ from traditional news media (printed newspapers, radio, and television) in that they offer a different and unique set of affordances for journalists, namely instantaneity, multimodality, interactivity, and hypertextuality (Bardoel \& Deuze, 2001; Deuze, 2003; Domingo, 2005; 
Hall, 2001; Kammer, 2013; Newhagen \& Rafaeli, 1996; Salaverría, 2005). Not all of these affordances are unique to news websites (for instance, radio and television also afford instantaneity), but what is unique is the specific constellation of affordances, which enables news dissemination in real time, by a multitude of modalities, with audience interaction, and through interconnected web pages. These affordances are, however, only potentialities as they represent what news workers can do but are not required to do; just because something is possible, it is not automatically necessary or desirable. Nevertheless, in my interviews, nearly all news workers acknowledge that they are highly attentive to using these four affordances, albeit to different extents.

The most focus is on instantaneity, which the research literature also highlights as a central affordances of news websites. Such a high priority of topicality is, of course, nothing new in connection with news production; as Rantanen (2009) points out, the very etymology of the word 'news' (in English as well as in many other languages) suggests a close connection with that which is new. Digitally transferred news further emphasizes its centrality: according to Domingo (2011, p. xv), for example, real-time coverage is now "the dominant paradigm of online journalism," and Hjarvard (2012b, p. 99) notes that "New media have placed an added premium on the immediacy of news." Overall, the news workers who I interviewed agree with the research literature. The editor-in-chief of the most-visited Danish news website, for example, told me during an interview that:

It's in the nature of the web that 'breaking news' and the things that happen right now are what work best on the web. That is where the web's in its element and where the web's better than all other media. (Geir Terje Ruud, Editor-in-Chief with responsibility for online operations at Ekstra Bladet, my translation)

The other three affordances also play important roles in the way news workers on news websites think of what they do, even if multimodality, interactivity, and hypertextuality are not equally prominent in the minds of news workers. However, the editor of Berlingske's news website expresses the overall attitude concerning the inclusion of multimodal and hypertextual features on news websites when he states:

We have a clear ambition that our stories be more than just text, that they contain rich content, that is, video, galleries, and links of any kind and preferably out of the site. [...] So, we want to make something on the premises of the net. (Troels B. Jørgensen, Online Editor at Berlingske, my translation)

The editor does not mention interactivity here, but I will return to the use of this affordance below, when presenting the trend of participatory audiences.

The extensive attention given to the affordances of news websites is not just a matter of news workers praising themselves in interviews, as we could be led to expect from the earlier findings. Engebretsen (2006), for instance, concludes from a comparative study of Scandinavian news websites that they use the affordances to only a very modest degree 
- and that Danish news websites, in particular, do not use them very much. But the high attention, that the interviewees express, is also apparent from two recent empirical studies of Danish news websites. First, a baseline study (in Kammer, 2013) of 93 Danish news websites' use of the concrete instantiations of the instantaneity, multimodality, interactivity, and hypertextuality affordances shows that the affordances are actually put to use in everyday journalism on Danish news websites. This finding supports the claims of the interviewees. Second, a case study of the real-time coverage of the July 22, 2011, terrorist attacks in Norway demonstrates how Danish and Norwegian news websites also use the affordances when covering extraordinary and highly unexpected events (in Kammer, 2013).

\section{2) Radical commercialization}

The second trend is the radical commercialization of journalism that has characterized recent years and has been particularly evident in relation to news on the web. It is a central development within contemporary journalism but is nonetheless only one of several current transformative processes. According to McQuail (2000, p. 105), commercialization within the field of media studies involves the increased influence of the market on media and their content. This is not to say that economic considerations and motivations have not always played a role in the media (see, e.g., Schudson, 2005), but much scholarly work argues that this dimension is increasing in importance and even constitutes a decisive factor in, for instance, news selection (McManus, 1994).

Over recent years, the news industry has become increasingly commercialized, and market pressures are increasingly influencing journalism. This commercialization is apparent in, among other things, the way that large-scale media corporations acquire other organizations, building conglomerates. Since the turn of the millennium, for instance, Berlingske Media, one of the largest Danish news organizations, has twice been bought up by large international corporations (Norwegian Orkla Media in 2000 and British Mecom Group in 2006). These acquisitions have fuelled expectations of operating profits, causing several cuts in the workforce and a broader scope of revenue-generating activities in the news organization. On the basis of a trans-Scandinavian study, Barland (2012) describes how news organizations are expanding and rethinking the traditional understanding of journalism in order to conduct activities that can generate revenue: if data-driven journalism about how to lose weight is what it takes to get audiences to buy memberships of weight-loss clubs, then that kind of journalism will indeed be conducted.

Furthermore, the process of commercialization is characterized by the arrival of a number of new actors that circulate news but have little to do with journalism. The most obvious example of this is probably Google, which operates Google News as an aggregation site that, using algorithms, presents news from a vast number of news websites without conducting any journalistic work itself. Such activities contribute to leading revenue streams away from the established news organizations. 
Concurrently, digital technology is playing heavily into the work journalists do. Most notably, the proliferation of technology that allows one to measure the readership of news on the web in real time and with great accuracy dovetails with the economic stress under which news organizations are operating (Grueskin, Seave \& Graves, 2011; Nielsen, 2012) and is having an increasing impact on the journalistic judgment of newsworthiness. In earlier, pre-digital journalism, journalists nearly took pride in not knowing their audiences and what parts of the newspapers they actually read (Schlesinger, 1978; Willig, 2010). With digital technology, such self-imposed ignorance has faded, and news workers now actively use real-time tracking of readership patterns to prioritize news stories and word headlines. As Hartley (2011) describes from ethnographic studies of news desks, editors of news websites - particularly those responsible for the front pages - use live measures of audience behavior to make decisions about which news stories should receive high priority and which should take secondary positions. One consequence of this practice is that stories that would not normally meet the traditional standards of newsworthiness are now published on the top of the front page since they generate page views (and thus advertisement exposure and income for the news organization). A commercial criterion therefore heavily influences the assessment of newsworthiness. Support for this claim is provided, for example, in this exchange from an interview I undertook with the online manager of a well-visited regional news website:

\footnotetext{
Interviewer: "So that [real-time tracking of readership] is a very important parameter in your prioritization of news?"

Interviewee: "It's actually the only parameter. We utterly do not care how relevant we think the story might be." (Grith Jørgensen, Site and Community Manager at Aarhus Stiftstidende, ${ }^{2}$ my translation)
}

Although the easygoing conversation in the interview situation might have caused this statement to be formulated somewhat more grandiloquently than intended, its meaning is clear: commercial considerations are of high priority and regularly outcompete traditional news values such as topicality, importance, proximity, etc. Instead, popular appeal has become a news value in itself, and articles about celebrities and cute baby animals are found even on non-tabloid news websites. Newsworthiness is thus transforming from being an institutionalized, occupational instrument for determining journalistic salience to becoming a means of honoring organizational demands by securing customers (cf. Örnebring, 2009). An even more radical development is the still-emerging algorithmic selection of news in which programmed command lines supplement - if not substitute - the selection work of front page editors, automatically prioritizing news stories on the basis of statistical measurements of readership patterns as a means of maximizing readership (Anderson, 2011; Schudson \& Fink, 2012).

The bias towards popular content is not, however, exclusive to online news: non-subscription newspapers have always decided which stories to place on the front page on the 
basis of what sells newspapers rather than on what is the most journalistically significant (Hjarvard, Kristensen, \& Ørsten, 2004). Even so, the points made here are examples of how the medium and its institutional logic influences if not downright subsumes the working of the journalistic institution.

\section{3) The participating audience}

The third trend is toward increased audience participation in news production. This trend is closely connected to the interactivity afforded by digital media as everyone with an internet connection can potentially upload content onto the web. The scholarly literature provides ample insight into how actors on the fringes of or beyond the journalistic institution undertake work resembling that of journalists (e.g., Deuze, 2007; Lowrey \& Latta, 2008; Russell, 2011). Also, within the established news organizations, "the people formerly known as the audience" (Rosen, 2006) have come to play an integral part in much of news making for the web.

According to Allan (2006), the event that constituted the breakthrough for audience participation in news production was the terrorist bombing of the London subway and a bus on July 7, 2005. Here, members of the audience uploaded more than 1,000 images and videos shot on mobile phones and added eyewitness accounts to the BBC's website in the immediate aftermath of the explosions, thereby providing the news organization with richer material for covering the emerging crisis than it would probably have been able to generate itself. Since then, there have been numerous examples of news workers drawing on the resources of their audiences: in 2008, for example, the Danish newspaper Berlingske Tidende's award-winning article series 'Forbrydelsen' ['The Crime'] concerning police failings was based almost entirely on audience contributions (see also Kammer, 2013), and in 2011, the Guardian had its audiences help the paper map the use of tracking cookies on websites. ${ }^{3}$ These are just two of the more prominent examples, and the cases of such participatory projects are legion. The Editor-in-Chief of Ekstrabladet.dk explains to me the advantages of this approach:

We try to communicate with the readers because the readers always have more knowledge
about what we write about than we do. You see, no matter what's going on, there are always at
least 50, probably 500 if not 5,000 people who know more about that which on which a jour-
nalist is writing. So if you can handle opening up your article for more information and knowl-
edge and advice from the readers, then your journalism will improve. In the same way, we ask
our readers for help getting, for example, images [...]. There are always some people who are
close to where things happen, and we can't be all over Denmark or the entire world. (Geir Terje
Ruud, Editor-in-Chief with responsibility for online operations at Ekstra Bladet, my translation)

Audiences being able to participate in some aspects of news production is nothing new - this possibility existed in the past with, for example, talk radio and newspapers. Now, however, it is much less laborious to have one's say, and audiences can participate in all 
stages of the news production process (Singer et al., 2011). Such participation can take several forms. As I have argued elsewhere (Kammer, 2013), audience participation in news production for news websites takes four different forms, namely that of providing information (members of the audience act as sources), that of collaboration (they conduct some of the reporting themselves), that of conversation (they engage in more social activities), and that of meta-communication (they draw attention to the very process of news production, thereby emphasizing issues of news media transparency and trustworthiness). Bødker (forthcoming/2013) further describes how audiences are increasingly operative in circulating news through social media in particular, thereby also participating in the creation of the framework for understanding the journalistic product.

Even though the trend of a participating audience is pervasive, it has not rendered institutional news workers obsolete. Through moderation and editing, it is still professional news workers who control what is published on news websites, and together with news agencies, they remain the producers of the vast majority of content (Hartley, 2009). But the relationship between institutional actors and audiences in news production is being transformed, and the professional role and position of journalists is being challenged.

\section{4) Multi-skilling and de-skilling}

The fourth and final trend is toward the simultaneous multi-skilling and de-skilling (or simply re-skilling, cf. Örnebring, 2009) of journalists, whose professional requirements are changing in the digital environment.

Multi-skilling is what occurs when journalists' professional competencies go beyond mere information gathering and processing and come to also include activities such as photography, copywriting, and typesetting (Bromley, 1997). This type of journalist has become increasingly prominent in the digital environment (Deuze, 2007; Steensen, 2010). The underlying logic is one of both technology and economy: as media have converged and all steps of the news-making process take place on compatible digital platforms, news organizations under commercial pressure can save resources by having journalists do more of the practical as well as the journalistic work connected to news making and news dissemination. Concretely, such multi-skilling leads to the kinds of work flows as the one described here by a journalist on a major Danish news website:

\footnotetext{
Interviewer: “Then, when you've made the article that's going to go online, do you set it up in some [content management] system and attach an image or what?"

Interviewee: "Yes. We [the journalists] do it all ourselves. And you can say, it's both good and bad. The good thing is that you learn to set it up, and you have a lot of influence concerning how your article is going to look. And where it's bad is that there is, of course, a margin or risk of error. Well, we don't have a fully functioning system for proofreading on the net, which we've asked for for many years, and it's expensive, and I know something is being worked on, and..." (Mikael Rømer, journalist at Ekstra Bladet, my translation)
} 
Journalists thus attend to a number of tasks that were once assigned to other types of news workers. As is also apparent from this statement, such multi-skilling may be reasonable in terms of economics but often comes at the price of quality. There are simply more errors and more half-baked news stories when the journalists must attend to technical tasks as well. Bardoel and Deuze (2001) make a similar observation when they posit that the most successful online newspapers are successful precisely because they resist the commercial logic to a certain extent and maintain a distinction between multi-skilled journalists and technical staffers. In their words, multi-skilling "does not mean that the journalist should be a technological freak, knowing her or his way around the complicated technology of today's newsroom [...] The technological team is integrated into the newsroom" (Bardoel \& Deuze, 2001).

The movement towards multi-skilling seems to be connected to some degree with the simultaneous de-skilling of journalists. In his study of German online newsrooms, Quandt (2008, p. 86) observes that "most of the time, the journalists are just regrouping, editing, and fine-tuning news agency stories," an observation that corresponds with Hartley's (2009) finding that the majority of news dissemination on the major Danish news websites consists of adjusted and perhaps marginally altered articles from news agencies. In a Benelux study, Deuze and Paulussen (2002) observe that online journalists only rarely leave the newsroom but conduct both research and interviews over the computers and telephones at their desks. The trend, then, is that as technology has made information gathering much easier, less journalistic activity is taking place 'in the field'.

These dual and opposing movements towards simultaneous multi-skilling and de-skilling may appear paradoxical. After all, how can you simultaneously have more skills and be less skilled? However, as Avilés et al. (2004, p. 99) explain, "Multi-skilling leaves journalists less time to fulfil traditional journalistic practices, such as double-checking of sources and finding contextual information." When they have to deal with many different tasks, fewer resources are available for what was traditionally the core task. The trend in the online newsrooms is thus for journalists and other news workers to increasingly become Jacks-ofall-trades yet masters of none.

\section{A weak mediatization of journalism}

Considered together, these four trends suggest that journalism is currently undergoing a mediatization process as the actors conducting it adapt to the logic of the medium rather than stick to their institutionalized practices. The most telling expression of such a mediatization process within journalism probably comes from the journalist who also gave an account of the practical procedure for publishing news online (see above). Answering a question concerning the news website's use of breaking news and real-time coverage, the journalist explains how the competition to always break the news first plays out at the news desk: 
All the time, every time we have some story, regardless of if it's a crime story, if it's a politics story, or sports, then we see that Ritzau's' also got it just a moment later [than us]. "Ritzau didn't have it until 14:58. That's funny, we had it at 14:54!" And it's ridiculous, but that's just the way it is... (Mikael Rømer, journalist at Ekstra Bladet, my translation)

This journalist's point is that the competition to be the first news website to break the news is so intense that it is basically a fight for minutes and seconds. But as soon as the news workers publish the story, the other media organizations, all of which closely monitor their competitors' news websites, immediately follow suit and publish similar stories, cancelling out the advantage of being the first website to break the news. In such a situation, does it really matter how fast one works?

The academic point to be made from this statement is, however, a different one, namely one of mediatization. The key is that the journalist considers this type of behavior "ridiculous". To him, it is an inappropriate allocation of resources - yet he nevertheless responds to the demands of the media institution and produces breaking news stories that competitors can then replicate or adapt moments later. This is Schrott's model in practice: a particular situation in which the demands of the media institution and its internal logic (which favors real-time news) influences the behavior of an individual so that he acts in a certain way (which he most likely would not have done otherwise) in order to accommodate the demand of the medium. Then, his activity again influences the social situation, emphasizing instantaneity as a constituent of the logic of the medium, thereby contributing to journalism being subsumed by the media institution. The particular action of the journalist - an action that he, his colleagues, and other news organizations reiterate again and again - is thus a tangible example of the process of mediatization of journalism as an interplay between structural changes on the macro level and transformation of individual behavior on the micro level.

Over the past 15-20 years, transformations within journalism have taken place because of developments outside of the institution itself. This development of institutional submission - from a situation in which the media served journalism to one in which journalism serves the media (Hjarvard, 2010) - is, however, not a strictly unidirectional or unequivocal one. To the contrary, individuals within the journalistic institution often oppose the mediatization process: In addition to a reluctance to follow the imperatives of the media institution, as expressed in the statement above, recent findings about journalists' attitudes toward audience participation indicate a struggle between the imperatives of the media and the practices of journalism. An international research group (Singer et al., 2011), for example, distinguishes between different stages of participation in the news production process, from conception of production to interpretation of the final product. One of the group's conclusions is that news workers are much more prone to welcome audience participation in the stages when it does not interfere with the editorial selection and writing of the news. These stages are regarded as exclusive to the news workers, and judging from my baseline study of the use of the four affordances on Danish news websites (Kammer, 2013), the actualizations 
of the interactivity affordance are also primarily the ones that do not compromise journalistic autonomy. This finding suggests that a reluctance or resistance towards mediatization exists within the journalistic institution, even while such a process is nevertheless in progress.

One implication of the mediatization of journalism is that journalism's type of professionalization is changing. The professional aspects of journalism have crystallized itself in the second half of the 20th century as a triangular hybrid of creative work, employment characterized by routines, and idealistic vocation (Kristensen, 2000). Drawing on Evetts' $(2003,2006)$ sociology of professions, however, Örnebring (2009) describes how journalism is currently undergoing a transformation from being an occupational profession to being an organizational profession. This transformation means that the actors within the institution or profession increasingly respond to organizational (that is, primarily commercial) demands than to the demands traditionally connected to the journalistic vocation. As a result, attention to public visibility and profitability have become more prominent while classic characteristics of journalism have receded. Hallin (2011) likewise argues that post-modern journalism is more opinionated, fragmented, and commercially oriented than journalism of the past. Journalists thus increasingly act as media professionals who comply with what the demands of the autonomous media institution, conducting mediatized journalism.

Since journalism and media formed a close nexus in the first place, the transformative process of journalism outlined in this research article is one of weak mediatization only, even though the consequences are profound for the institutions and the actors within it. It is nothing new for journalism to accommodate the formal limitations of the media dictated by fixed deadlines, the dimensions of a newspaper page, the duration of a news broadcast, etc. What is new and what is worth further academic scrutiny in future studies is the way in which this accommodation takes place and its increased radicalization relative to news on both the web and other types of news media.

\section{Notes}

1. Because mediatization thus concerns change and transformation, it should not be confused with mediation, which entails first and foremost that communication does not take place face-to-face but relies on some sort of medium technology.

2. It should be noted that, since this interview was conducted, the news website has raised a paywall around all its content, changing the economic context of the news selection.

3. See http://www.b.dk/forbrydelsen and http://www.guardian.co.uk/technology/2012/apr/13/trackingthe-trackers-cookies-web-monitors, respectively.

4. Ritzau is the leading news agency in Denmark. 


\section{References}

Allan, S. (2006). Online News. Journalism and the Internet. Maidenhead: Open University Press.

Altheide, D.L., \& Snow, R.P. (1979). Media Logic. Beverly Hills: Sage.

Anderson, C.W. (2011). Deliberative, Agonistic, and Algorithmic Audiences: Journalism's Vision of its Public in an Age of Audience Transparency. International Journal of Communication, 5, 529-547.

Anderson, C.W. (2013). Rebuilding the News: Metropolitan Journalism in the Digital Age Philadelphia: Temple University Press.

Avilés, J.A.G., León, B., Sanders, K., \& Harrison, J. (2004). Journalists at digital television newsrooms in Britain and Spain: workflow and multi-skilling in a competitive environment. Journalism Studies, 5(1), 87-100.

Bardoel, J., \& Deuze, M. (2001). Network Journalism: Converging Competences of Media Professionals and Professionalism. Australian Journalism Review, 23(2), 91-103.

Barland, J. (2012). Journalistikk for markedet [Journalism for the market]. Oslo: University of Oslo.

Boczkowski, P.J. (2004). Digitizing the News. Innovation in Online Newspapers. Cambridge: The MIT Press.

Bromley, M. (1997). The End of Journalism? Changes in workplace practices in the press and broadcasting in the 1990s. In M. Bromley \& T. O'Melley (Eds.), A Journalism Reader (pp. 330-350). London: Routledge.

Bruno, N., \& Nielsen, R.K. (2012). Survival is Success. Journalistic Online Start-Ups in Western Europe. Oxford: Reuters Institute for the Study of Journalism.

Bødker, H. (forthcoming/2013). Sociale medier som journalistisk kommentarfilter [Social media as journalistic commentary filter]. In J.L. Jensen \& J. Tække (Eds.), Facebook i den danske hverdag - fra socialt netverk til metamedie. Frederiksberg: Samfundslitteratur.

Cook, T.E. (2005). Governing with the News. The News Media as a Political Institution (2nd ed.). Chicago: The University of Chicago Press.

Couldry, N. (2008). Mediatization or mediation? Alternative understandings of the emergent space of digital storytelling. New Media \& Society, 10(3), 373-391.

Couldry, N. (2012). Media, Society, World: Social Theory and Digital Media Practice. Cambridge: Polity Press.

Deuze, M. (2003). The web and its journalisms: considering the consequences of different types of newsmedia online. New Media \& Society, 5(2), 203-230.

Deuze, M. (2005). What is journalism?: Professional identity and ideology of journalists reconsidered. Journalism, 6(4), 442-464.

Deuze, M. (2007). Media Work. Cambridge: Polity Press.

Deuze, M. (2008). Understanding Journalism as Newswork: How It Changes, and How It Remains the Same. Westminster Papers in Communication and Culture, 5(2), 4-23.

Deuze, M. (Ed.). (2011). Managing Media Work. Los Angeles: Sage.

Deuze, M., \& Paulussen, S. (2002). Research Note: Online Journalism in the Low Countries. European Journal of Communication, 17(2), 237-245.

Domingo, D. (2005). The difficult shift from utopia to realism in the Internet era. A decade of online journalism research: theories, methodologies, results and challenges. Paper presented at the First European Communication Conference, Amsterdam, November 24-26, 2005.

Domingo, D. (2008). Interactivity in the daily routines of online newsrooms: dealing with an uncomfortable myth. Journal of Computer-Mediated Communication, 13(3), 680-704.

Domingo, D. (2011). Introduction: The Centrality of Online Journalism Today (and Tomorrow). In D. Domingo \& C. Paterson (Eds.), Making Online News, Volume 2: Newsroom Ethnographies in the Second Decade of Internet Journalism (pp. xiii-xx). New York: Peter Lang.

Easton, D. (1971). The Political System. An Inquiry into the State of Political Science (2nd ed.). New York: Alfred A. Knopf.

Eide, M. (2011). Hva er journalistikk [What is journalism]. Oslo: Universitetsforlaget. 
Engebretsen, M. (2006). Shallow and Static or Deep and Dynamic? Nordicom Review(27), 3-16.

Erdal, I.J. (2008). Cross-Media News Journalism. Institutional, Professional and Textual Strategies and Practices in Multi-Platform News Production. Oslo: University of Oslo.

Evetts, J. (2003). The Sociological Analysis of Professionalism. International Sociology, 18(2), 395-415.

Evetts, J. (2006). Short Note: The Sociology of Professional Groups. Current Sociology, 54(1), 133-143.

Giddens, A. (1984). The Constitution of Society. Outline of the Theory of Structuration. Cambridge: Polity Press.

Giddens, A. (1986). Sociology. A brief but critical introduction (2nd ed.). Houndmills: Macmillan.

Grueskin, B., Seave, A., \& Graves, L. (2011). The Story So Far. What We Know About the Business of Digital Journalism. New York: Tow Center for Digital Journalism, Columbia Journalism School.

Hall, J. (2001). Online Journalism. A Critical Primer. London: Pluto Press.

Hallin, D.C. (2011). Postmodernism, Neoliberalism and Convergence: The Transformation of Journalism as a Social Institution. Paper presented at the Journalistic Reorientations conference, Bergen, November 2-4, 2011.

Hartley, J.M. (2009). Netjournalistik: Uden saks og klister... [Net journalism] In A.B. Lund, I. Willig \& M. BlachØrsten (Eds.), Hvor kommer nyhederne fra? Den journalistiske fødekcede i Danmark før og nu (pp. 149161). Aarhus: Ajour.

Hartley, J.M. (2011). Radikalisering af kampzonen. En analyse af netjournalistisk praksis og selvforståelse i spæendingsfeltet mellem idealer og publikum [Radicalization of the combat zone]. Roskilde: Roskilde University.

Hermida, A., \& Thurman, N. (2008). A Clash of Cultures. The integration of user-generated content within professional journalistic frameworks at British newspaper websites. Journalism Practice, 2(3), 343-356.

Hjarvard, S. (2004). From Bricks to Bytes: The Mediatization of a Global Toy Industry. In I. Bondebjerg \& P. Golding (Eds.), European Culture and the Media (pp. 43-63). Bristol: Intellect Books.

Hjarvard, S. (2005). Medialisering af religiøse forestillinger [The mediatization of religious beliefs]. In M.T. Højgaard \& H.R. Iversen (Eds.), Gudstro i Danmark (pp. 167-186). Frederiksberg: Forlaget ANIS.

Hjarvard, S. (2008a). En verden af medier. Medialiseringen af politik, sprog, religion og leg [A world of media]. Frederiksberg: Samfundslitteratur.

Hjarvard, S. (2008b). The mediatization of religion. A theory of the media as agents of religious change. Northern Lights. Film and Media Studies Yearbook, 6, 9-26.

Hjarvard, S. (2008c). The Mediatization of Society. A Theory of the Media as Agents of Social and Cultural Change. Nordicom Review, 29, 105-134.

Hjarvard, S. (2009). Soft Individualism: Media and the Changing Social Character. In K. Lundby (Ed.), Mediatization. Concept, changes, consequences (pp. 159-177). New York: Peter Lang.

Hjarvard, S. (2010). The mediatization of journalism. Institutional transformations in a new media environment. Paper presented at the Journalism, Institutions and Politics conference, Copenhagen, November $18,2010$.

Hjarvard, S. (2012a). Doing the Right Thing. Media and Communication Studies in a Mediatized World. Nordicom Review, Supplement, 33(1), 27-34.

Hjarvard, S. (2012b). The study of news production. In K.B. Jensen (Ed.), A Handbook of Media and Communication Research. Qualitative and quantitative methodologies (2nd ed., pp. 87-105). London: Routledge. Hjarvard, S. (2013). The Mediatization of Culture and Society. London: Routledge.

Hjarvard, S., \& Finnemann, N.O. (2009). Medialisering 1 [Mediatization 1]. In S. Kolstrup, G. Agger, P. Jauert \& K. Schrøder (Eds.), Medie- og kommunikationsleksikon (p. 311). Frederiksberg: Samfundslitteratur.

Hjarvard, S., Kristensen, N.N., \& Ørsten, M. (2004). Mediernes daekning af invasionen af Irak 2003 [The media coverage of the invasion of Iraq 2003]. Copenhagen: MODINET. 
Huntington, S.P., \& Dominguez, J.I. (1975). Political Development. In F.I. Greenstein \& N.W. Polsby (Eds.), Handbook of Political Science (Vol. 3, pp. 1-114). Reading: Addison-Wesley.

llebekk, S. (2000). Nyhetsformidling på internett. En sammenligning av en papiravis og nettaviser [News dissemination on the internet]. Bergen: Department of Media Studies, University of Bergen.

Kammer, A. (2013). News on the Web: instantaneity, multimodality, interactivity, and hypertextuality on Danish news websites. Copenhagen: University of Copenhagen.

Kristensen, N.N. (2000). Journalistik som profession. Om journalistens rolleplacering i et professionssociologisk perspektiv. [Journalism as profession] In F. Henriksen (Ed.), Sekvens 2000: Mediesociologi (pp. 159184). Copenhagen: Department of Film and Media Studies, University of Copenhagen.

Krumsvik, A.H. (2009). The Online News Factory. A Multi-Lens Investigation of the Strategy, Structure, and Process of Online News Production at CNN and NRK. Oslo: University of Oslo.

Kvale, S. (1997). Interview. En introduktion til det kvalitative forskningsinterview [Interview]. Copenhagen: Hans Reitzels Forlag.

Lowrey, W., \& Latta, J. (2008). The Routines of Blogging. In C. Paterson \& D. Domingo (Eds.), Making Online News: The Ethnography of New Media Production (pp. 185-197). New York: Peter Lang.

Lundby, K. (2009a). Introduction: 'Mediatization' as Key. In K. Lundby (Ed.), Mediatization. Concept, changes, consequences (pp. 1-18). New York: Peter Lang.

Lundby, K. (2009b). Media Logic: Looking for Social Interaction. In K. Lundby (Ed.), Mediatization. Concept, changes, consequences (pp. 101-119). New York: Peter Lang.

Mazzoleni, G., \& Schulz, W. (1999). "Mediatization" of Politics: A Challenge for Democracy? Political Communication, 16(3), 247-261.

McManus, J.H. (1994). Market-Driven Journalism. Let the Citizen Beware? Thousand Oaks: Sage.

McQuail, D. (2000). McQuail's Mass Communication Theory (4th ed.). Los Angeles: Sage.

Newhagen, J.E., \& Rafaeli, S. (1996). Why Communication Researchers Should Study the Internet: A Dialogue. Journal of Communication, 46(1), 4-13.

Newman, N. (2011). Mainstream media and the distribution of news in the age of social discovery. Oxford: Reuters Institute for the Study of Journalism.

Nielsen, R.K. (2012). Ten Years that Shook the Media World. Big Questions and Big Trends in International Media Developments. Oxford: Reuters Institute for the Study of Journalism.

Petersen, L.N. (2012). Wicked Angels, Adorable Vampires! Religion, amerikanske serier og danske teenagere [Wicked Angels, Adorable Vampires!]. Copenhagen: University of Copenhagen.

Quandt, T. (2008). News Tuning and Content Management: An Observation Study of Old and New Routines in German Online Newsrooms. In C. Paterson \& D. Domingo (Eds.), Making Online News: The Ethnography of New Media Production (pp. 77-97). New York: Peter Lang.

Rantanen, T. (2009). When News Was New. Malden: Wiley-Blackwell.

Rosen, J. (2006). The People Formerly Known as the Audience. PressThink. Ghost of Democracy in the Media Machine. Retrieved January 10, 2013, from http://archive.pressthink.org/2006/06/27/ppl_frmr.html.

Russell, A. (2011). Networked. A Contemporary History of News in Transition. Cambridge: Polity Press.

Salaverría, R. (2005). An Immature Medium. Strengths and Weaknesses of Online Newspapers on September 11. Gazette: The International Journal for Communication Studies, 67(1), 69-86.

Schlesinger, P. (1978). Putting 'reality' together: BBC News. London: Constable.

Schrott, A. (2009). Dimensions: Catch-All Label or Technical Term. In K. Lundby (Ed.), Mediatization. Concept, changes, consequences (pp. 41-61). New York: Peter Lang.

Schudson, M. (2005). Four Approaches to the Sociology of News. In J. Curran \& M. Gurevitch (Eds.), Mass Media and Society (4th ed., pp. 172-197). London: Hodder Arnold. 
Schudson, M., \& Fink, K. (2012). The Algorithm Method. Making news decisions in a clickocracy. Columbia Journalism Review, 50(5), 63.

Singer, J.B., Hermida, A., Domingo, D., Heinonen, A., Paulussen, S., Quandt, T., et al., (Eds.). (2011). Participatory Journalism: Guarding Open Gates at Online Newspapers. Malden: Wiley-Blackwell.

Steensen, S. (2010). Back to the Feature. Online journalism as innovation, transformation and practice. Oslo: University of Oslo.

Steensen, S. (2011). Cozy Journalism. The rise of social cohesion as an ideal in online, participatory journalism. Journalism Practice, 5(6), 687-703.

Strömbäck, J., \& Esser, F. (2009). Shaping Politics: Mediatization and Media Interventionism. In K. Lundby (Ed.), Mediatization. Concept, changes, consequences (pp. 205-223). New York: Peter Lang.

Thurman, N., \& Walters, A. (2013). Live Blogging-Digital Journalism's Pivotal Platform? A case study of the production, consumption, and form of Live Blogs at Guardian.co.uk. Digital Journalism, 1(1), 82-101.

van der Wurff, R., \& Lauf, E. (Eds.). (2005). Print and Online Newspapers in Europe. A comparative analysis in 16 countries. Amsterdam: Het Spinhuis.

Wallberg, F. (2012). I Like News. Nyheder på Facebook. [I Like News] Odense: Centre for Journalism, University of Southern Denmark.

Willig, I. (2010). Constructing the audience: a study of segmentation in the Danish press. Northern Lights. Film and Media Studies Yearbook, 8, 93-114.

Zelizer, B. (2005). The Culture of Journalism. In J. Curran \& M. Gurevitch (Eds.), Mass Media and Society (4th ed., pp. 198-214). London: Hodder Arnold.

Örnebring, H. (2009). The Two Professionalisms of Journalism: Journalism and the changing context of work. Oxford: Reuters Institute for the Study of Journalism.

Aske Kammer

External Lecturer, PhD

Department of Media, Cognition, and Communication

University of Copenhagen, Denmark

askammer@hum.ku.dk 